UDC 554544.654 .2

\title{
MATHEMATICAL MODELING AND OPTIMIZATION OF THE LECTRODEPOSITION PROCESS OF ANTIMONY-SELENIUM SYSTEM
}

\author{
V.A.Majidzade, G.S.Aliyev, A.Sh.Aliyev, R.H.Huseynova, Z.M.Mammadova \\ M.Nagiyev Institute of Catalysis and Inorganic Chemistry, NAS of Azerbaijan \\ vuska_80@mail.ru
}

Received 24.03.2020

Accepted 22.06.2020

\begin{abstract}
Antimony selenide $\left(\mathrm{Sb}_{2} \mathrm{Se}_{3}\right)$, is an excellent photovoltaic absorber due to its high absorption coefficient $\left(>10^{5} \mathrm{~cm}^{-1}\right)$ at the visible region and $1.17 \mathrm{eV}$ band gap. In recent years, the power conversion efficiency of $\mathrm{Sb}_{2} \mathrm{Se}_{3}$ thin film solar cells has gradually enhanced. Therefore, given the great interest in this materi$\mathrm{al}$, this work is devoted to the study of a mathematical model for the optimization of the preparation of thin $\mathrm{Sb}-\mathrm{Se}$ films by the electrochemical method. The study was conducted by potentiodynamic, potentiostatic and galvanostatic methods carried out under different conditions at $\mathrm{Pt}, \mathrm{Cu}$ and Ni electrodes. The kinetics and mechanism of the electroreduction of antimony and selenite ions in the tartaric acid were studied separately for the electrochemical deposition. On the basis of cyclic polarization, X-ray phase and SEM-EDX analyses, it is found that $\mathrm{Sb}-\mathrm{Se}$ thin films are deposited on $\mathrm{Pt}$ and Ni electrodes, but not on $\mathrm{Cu}$ electrode. The mathematical calculations were performed in the OptimME software package using specially developed software for this process. By studying the effects of various factors (concentration of the initial components, temperature, current density, etc.), the optimal electrolysis mode and electrolyte composition for the co-deposition process were selected. Based on these results, Student and Fisher criteria were assigned for future purposes and regression coefficients were estimated. The obtained regression equation determines the electrolyte content and the electrolysis conditions, which allows precipitating the $\mathrm{Sb}-\mathrm{Se}$ alloy containing the required amount of $\mathrm{Sb}$. Calculations and experimental results show that the error of the regression equation for obtaining the $\mathrm{Sb}-\mathrm{Se}$ alloy is $\varepsilon=6.4 \%$.
\end{abstract}

Keywords: Sb-Se films, regression equation, Student and Fisher criteria, mathematical modeling.

doi

\section{Introduction}

In the modern age, in connection with the development of nanotechnology, the production of thin layers and nanostructures [1-10], with a given composition has become an important task for chemists and physicists. As is known, these thin films according to the value of the band gap can be used in magnetic media, electronic and optical devices, LEDs, as well as thin-layer solar panels for energy production and putting away $[11,12]$. The preparation of such thin films by the electrochemical method is a consistent continuation of our work. In this contribution, firstly we study the process of electrochemical reduction of the initial components separately [13-15], and then carry out the co-deposition process [8].

Upon receipt of thin films, some factors influence the process - the concentration of the components in the electrolyte, the current density passing through the electrolyte, the tempera- ture of the electrolyte, etc. which changes the direction of the electrochemical processes via varying their values. Therefore, to determine the optimal regime, it is necessary to conduct numerous experiments. This requires a long time and creates difficulties in solving the problem. Therefore, the construction of a mathematical model of the process, based on the results of many experiments helps to minimize the number of reagents used in the process, reduces the number of experiments performed, and this reduces the research time.

Mathematical modeling is a powerful tool for solving various problems that arise while optimizing chemical processes and obtaining maximum profitability. The nature of the effects of changes in the parameters of each chemical process also affects its results. From this point of view, by constructing a mathematical model of the process, choosing the most optimal parameters, can be expressed as a mathe- 
matical function, which can help increase the output by reducing the cost of the process. Therefore, the mathematical model should not only accurately describe the actual process, but also be simple and ensure the accuracy of the calculations.

As is known, thin $\mathrm{Sb}_{2} \mathrm{Se}_{3}$ semiconductor films possess high optical, electrical, thermoelectric, etc. properties. From this point of view, they are widely used in electronics and electrical engineering, solar cells, integrated circuits, transistors, optical detectors, etc. Therefore, given the breadth of the field of application of $\mathrm{Sb}_{2} \mathrm{Se}_{3}$ [16-20], mathematical modeling of electrochemical deposition of the $\mathrm{Sb}-\mathrm{Se}$ system can be of great practical importance.

Based on a study of the results of processes by methods of mathematical statistics, it is possible to study the influence of the main parameters on the course of the process and determine its optimal modes. To confirm the obtained experimental results, the regression equations are constructed, the criteria of significance and adequacy are calculated [21-25]. It was this technique that was applied to the process of deposition of thin $\mathrm{Sb}-\mathrm{Se}$ films under study.

\section{Experimental part}

When compiling a mathematical model of the $\mathrm{Sb}-\mathrm{Se}$ electrodeposition process, we used the experimental data obtained as a result our experiments $[8,13,15,19,20]$. To confirm the results of the experiment, based on the obtained data, a regression equation was compiled, and criteria of significance and adequacy were calculated [21-25].

Calculations are performed by specially developed software for this process. When planning a full factorial experiment (FFE) of this process, all possible combinations of factors are implemented at all selected levels for the study. The required number of experiments $N$ with FFE is determined by the formula $N=2^{k}$, where $k$-is the number of factors.

\section{Results and discussion}

The influence of four factors on the antimony deposition process during joint deposition was studied: the concentration of $\mathrm{SbOCl}\left(\mathrm{Z}_{1}\right)$ in the range of $0.01-0.09 \mathrm{~mol} / \mathrm{L}$, the concentration of $\mathrm{H}_{2} \mathrm{SeO}_{3}\left(Z_{2}\right)$ in the range of $0.01-0.09 \mathrm{~mol} / \mathrm{L}$, and the current density $\left(Z_{3}\right)$ in in the range of 20-60 mA cm${ }^{-2}$, temperature $\left(Z_{4}\right)$ - in the range of $25-85^{\circ} \mathrm{C}$. Then,

$$
\begin{aligned}
& Z_{j}^{0}=\frac{Z_{j}^{\max }+Z_{j}^{\min }}{2}, \\
& \Delta Z_{j}=\frac{Z_{j}^{\max }-Z_{j}^{\min }}{2}, \\
& j=1,2,3,4 .
\end{aligned}
$$

Using these formulas we get:

$$
\begin{aligned}
& Z_{1}^{0}=\frac{0.01+0.09}{2}=0.05 \\
& \Delta Z_{1}=\frac{0.09-0.01}{2}=0.04, \\
& Z_{2}^{0}=0.05, \Delta Z_{2}=0.04, \\
& Z_{3}^{0}=40, \Delta Z_{3}=20 \\
& Z_{4}^{0}=55, \Delta Z_{4}=30 .
\end{aligned}
$$

The following formula was used to move from factors with natural scale to dimensionless factors:

$$
x_{j}=\frac{Z_{j}-Z_{j}^{0}}{\Delta Z_{j}}, \quad j=1,2,3,4
$$

For example,

at $\quad Z_{1}=0.01, x_{1}=\frac{0.01-0.05}{0.04}=-1$.

The number of possible combinations at four factors is equal to $N=2^{4}=16$. The experimental design (planning matrix) is shown in the Table.

The coefficients of the regression equation were determined by the least squares method as follows. Any coefficient in the regression equation $b_{j}$ is determined by the scalar product of the column $y$ by the corresponding column $x_{j}$ divided by the number of experiments in the planning matrix $N=16$ :

$$
b_{j}=\frac{1}{16} \sum_{i=1}^{16} x_{j i} y_{i} \text {. }
$$


The planning matrix of experiments

\begin{tabular}{|c|c|c|c|c|c|c|c|c|c|}
\hline \multirow{2}{*}{$№$} & \multicolumn{3}{|c|}{ Factors on a natural scale } & \multicolumn{3}{c|}{ Dimensionless Factors } & \multirow{2}{*}{$y$} \\
\cline { 2 - 10 } & $Z_{1}$ & $Z_{2}$ & $Z_{3}$ & $Z_{4}$ & $x_{1}$ & $x_{2}$ & $x_{3}$ & $x_{4}$ & -1 \\
\hline 1 & 0.01 & 0.01 & 20 & 25 & -1 & -1 & -1 & -1 & -1 \\
\hline 2 & 0.01 & 0.01 & 20 & 85 & -1 & -1 & -1 & +1 & 86.5 \\
\hline 3 & 0.01 & 0.01 & 60 & 25 & -1 & -1 & +1 & -1 & 51.8 \\
\hline 4 & 0.01 & 0.01 & 60 & 85 & -1 & -1 & +1 & +1 & 75.1 \\
\hline 5 & 0.01 & 0.09 & 20 & 25 & -1 & +1 & -1 & -1 & 54.3 \\
\hline 6 & 0.01 & 0.09 & 20 & 85 & -1 & +1 & -1 & +1 & 42.8 \\
\hline 7 & 0.01 & 0.09 & 60 & 25 & -1 & +1 & +1 & -1 & 34.2 \\
\hline 8 & 0.01 & 0.09 & 60 & 85 & -1 & +1 & +1 & +1 & 11.7 \\
\hline 9 & 0.09 & 0.01 & 20 & 25 & +1 & -1 & -1 & -1 & 87.8 \\
\hline 10 & 0.09 & 0.01 & 20 & 85 & +1 & -1 & -1 & +1 & 74.7 \\
\hline 11 & 0.09 & 0.01 & 60 & 25 & +1 & -1 & +1 & -1 & 51.2 \\
\hline 12 & 0.09 & 0.01 & 60 & 85 & +1 & -1 & +1 & +1 & 39.7 \\
\hline 13 & 0.09 & 0.09 & 20 & 25 & +1 & +1 & -1 & -1 & 87.8 \\
\hline 14 & 0.09 & 0.09 & 20 & 85 & +1 & +1 & -1 & +1 & 68.3 \\
\hline 15 & 0.09 & 0.09 & 60 & 25 & +1 & +1 & +1 & -1 & 51.2 \\
\hline 16 & 0.09 & 0.09 & 60 & 85 & +1 & +1 & +1 & +1 & 43.1 \\
\hline
\end{tabular}

Using the plan presented in the table, we first calculated the coefficients of the linear regression equation:

$$
y=b_{0}+b_{1} x_{1}+b_{2} x_{2}+b_{3} x_{3}+b_{4} x_{4} .
$$

For example, to determine the coefficient $b_{1}$ at $x_{1}$, it is necessary to obtain the sum of the products:

$$
\sum_{i=1}^{16} x_{1 i} y_{i}=70.6, \quad b_{1}=\frac{\sum_{i=1}^{16} x_{1 i} y_{i}}{16}=\frac{70.6}{16}=4.4 \text {. }
$$

Similarly obtained $b_{0}=58.6, b_{2}=-9.4$, $b_{3}=-13.8, b_{4}=-3.3$.

Then the linear regression equation is:

$$
y=58.6+4.4 x_{1}-9.4 x_{2}-13.8 x_{3}-3.3 x_{4} \text {. }
$$

To obtain a more complete regression equation, the interaction coefficients were introduced:

$$
\begin{aligned}
& \hat{y}=b_{0}+b_{1} x_{1}+b_{2} x_{2}+b_{3} x_{3}+b_{4} x_{4}+b_{12} x_{1} x_{2}+ \\
& +b_{13} x_{1} x_{3}+b_{14} x_{1} x_{4}+b_{23} x_{2} x_{3}+b_{24} x_{2} x_{4}+ \\
& +b_{34} x_{3} x_{4}+b_{123} x_{1} x_{2} x_{3}+b_{124} x_{1} x_{2} x_{4}+ \\
& +b_{134} x_{1} x_{3} x_{4}+b_{234} x_{2} x_{3} x_{4}+b_{1234} x_{1} x_{2} x_{3} x_{4} .
\end{aligned}
$$

The interaction coefficients are determined in the same way as linear coefficients. For example, to calculate the coefficient $b_{12}$, we need to perform the following operation:

$$
b_{12}=\frac{\sum_{i=1}^{16}\left(x_{1} x_{2}\right)_{i} y_{i}}{16}=9 .
$$

The remaining coefficients were determined in the same way:

$b_{13}=-2.9, b_{14}=-3.2, b_{23}=-0.3, b_{24}=-4.4$, $b_{34}=1, b_{123}=1.5, b_{124}=4, b_{134}=0.65, b_{234}=$ $-0.9, b_{1234}=2.15$.

Also, additional experiments were carried out to determine the significance of the regression coefficients and the adequacy of the equation.

Since the covariance matrix $\left(X^{T} X\right)^{-1}$ for a planned experiment is diagonal, the coefficients of the regression equation are uncorrelated with each other. The significance of the coefficients of the regression equation was checked for each coefficient individually according to the Student criterion. The exclusion of an insignificant coefficient from the regression equation will not affect the remaining coefficients. That is, the values of the coefficients of the regression equation characterize the contribution of the corresponding factor to the value of $y$. The diagonal elements of the covariance matrix are equal to each other; therefore, all the coefficients of equations (3) and (4) are determined with the same accuracy:

$$
S_{b j}=S / \sqrt{\mathrm{N}} \text {. }
$$


For example, in the center of the plan, three additional experiments are set and the following values of $y$ are obtained:

$$
\begin{gathered}
y_{1}^{0}=48.7 ; y_{2}^{0}=47.8 ; y_{3}^{0}=49.4, \\
\bar{y}^{0}=\frac{\sum_{n=1}^{3} y_{n}^{0}}{3}=48.63, \\
S^{2}=\frac{\sum_{n=1}^{3}\left(y_{n}^{0}-\bar{y}^{0}\right)^{2}}{3}=\frac{0.0044+0.111+0.071}{3}=0.43, \\
S=\sqrt{0.43}=0.66, \\
S_{b j}=0.66 / \sqrt{16}=0.17 .
\end{gathered}
$$

Assessment of the significance of the coefficients is made according to the Student criterion: $t_{0}=\frac{\left|b_{0}\right|}{S_{b o}}=\frac{58.6}{0.17} \approx 344.7$,

where, $S_{b 0}-$ is the standard deviation of the experiments.

Table values of the Student criterion for the significance level $p=0.05$ and the degree of freedom $f=2$ is equal to $t_{p}(f)=4.3$. All the determined coefficients were significant by the Student criterion, except for the coefficients $b_{23}$ and $b_{134}$, which can be neglected. After eliminating insignificant coefficients, the regression equation takes the following form:

$y=58.6+4.4 x_{1}-9.4 x_{2}-13.8 x_{3}-3.3 x_{4}+9 x_{1} x_{2}-$ $-2.9 x_{1} x_{3}-3.2 x_{1} x_{4}-4.4 x_{2} x_{4}+x_{3} x_{4}+1.5 x_{1} x_{2} x_{3}+$ $4 x_{1} x_{2} x_{4}-0.9 x_{2} x_{3} x_{4}+2.15 x_{1} x_{2} x_{3} x_{4}$.

Using the formula (1), we made the transition from a dimensionless scale to a natural scale. As a result, the following regression equation was obtained:

$$
\begin{aligned}
& y=92.25-17.45 Z_{1}-320 Z_{2}-0.91 Z_{3}+0.05 Z_{4}+ \\
& +4007 Z_{1} Z_{2}+0.05 Z_{1} Z_{3}-2.5 Z_{1} Z_{4}+5.85 Z_{2} Z_{3}- \\
& -1.9 Z_{2} Z_{4}+0.0095 Z_{3} Z_{4}-74.1 Z_{1} Z_{2} Z_{3}- \\
& -4.7 Z_{1} Z_{2} Z_{4}-0.11 Z_{1} Z_{3} Z_{4}-0.15 Z_{2} Z_{3} Z_{4}+ \\
& +2.2 Z_{1} Z_{2} Z_{3} Z_{4}
\end{aligned}
$$

The adequacy of equation (7) was determined by the formula:

$$
\varepsilon=\frac{\sum\left(\frac{C^{\exp }-C^{c a l}}{C^{\exp }}\right)^{2}}{16} * 100 \% .
$$

As a result of the calculations, the error determined by equation (7) is $\varepsilon=6.4 \%$. Thus, it can be concluded that the regression equation adequately describes this process. Based on function (7) and limiting factors, the problem of nonlinear optimization was posed and solved, and technological conditions that ensure the maximum value of the function $y$ were determined. The following values of parameter $-Z_{1}=0.09, Z_{2}=0.01, Z_{3}=20$ and $Z_{4}=25$ provide the maximum value of the objective function, which is equal to $y_{\max }=87.5 \%$.

To verify the fact that the derived mathematical model accurately describes the process of co-precipitation of antimony with selenium, experiments were carried out with arbitrarily chosen parameters. In the figures 1,2 , and 3 show the dependences of the alloy composition on the concentration of antimony (Figure 1), on the concentration of selenium (Figure 2), and on the current density (Figure 3 ) obtained by the experimental and calculated methods.

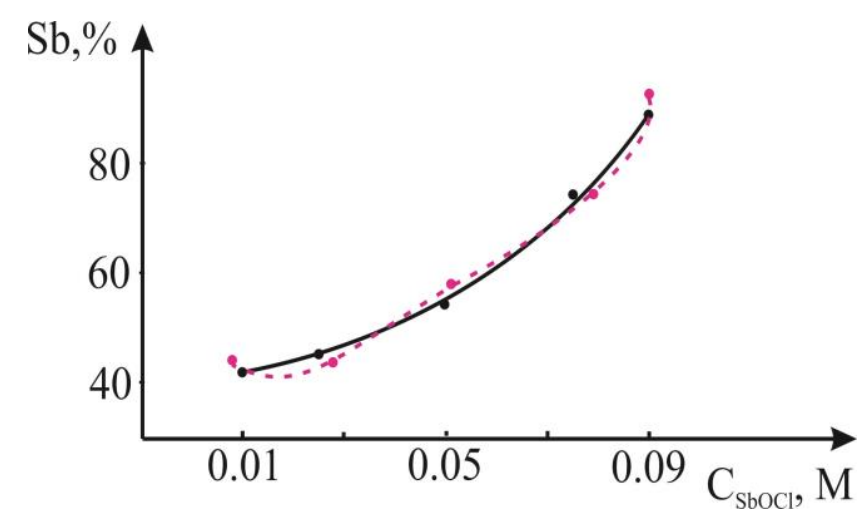

Fig. 1. Dependence of the antimony content in sediments on the concentration of $\mathrm{SbOCl}$ in the electrolyte. The composition of the electrolyte (M): 0.05 $\mathrm{H}_{2} \mathrm{SeO}_{3}+0.007 \mathrm{C}_{4} \mathrm{H}_{6} \mathrm{O}_{6} . i_{\mathrm{K}}=20 \mathrm{~mA} / \mathrm{cm}^{2}, T=298 \mathrm{~K}$.

The solid lines correspond to the calculated data obtained from equation (4), and the dashed lines - correspond to the experimental data. Comparison of the calculated data with the results obtained by the experimentally proves that the process of co-deposition is rather accurately described by equation (4) 


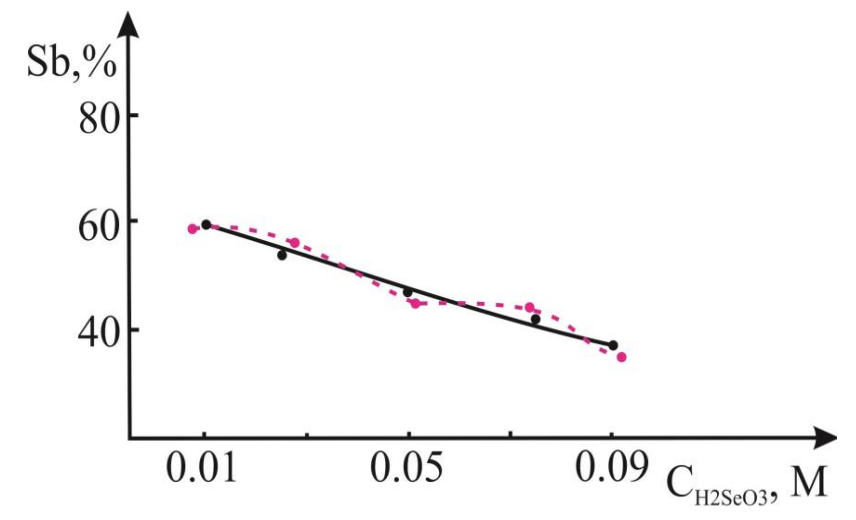

Fig. 2. Dependence of the antimony content in the alloy on the concentration of $\mathrm{H}_{2} \mathrm{SeO}_{3}$ in the electrolyte. The composition of the electrolyte (M): 0.05 $\mathrm{SbOCl}+0.05 \mathrm{H}_{2} \mathrm{SeO}_{3}+0.007 \mathrm{C}_{4} \mathrm{H}_{6} \mathrm{O}_{6} ; i_{\mathrm{K}}=20 \mathrm{~mA} / \mathrm{cm}^{2}$, $T=298 \mathrm{~K}$.

The obtained regression equation allows one to calculate the amount of antimony in $\mathrm{Sb}-$ Se electrolytic alloys at given concentrations of alloy components and describes the process of electrodeposition of antimony with selenium quite accurately, determining the relationship between the alloy composition, the electrolyte composition and electrolysis parameters.

\section{Conclusion}

Thus, the obtained regression equation (7) allows us to calculate the amount of antimony $\mathrm{Sb}-\mathrm{Se}$ in the alloy and determine the relationship between the alloy composition, electrolysis parameters and the electrolyte composition.

\section{References}

1. Costa M.B., Francisco W.S. Lucas, Mascaro L.H. Electrodeposition Conditions Effect $\mathrm{Sb}_{2} \mathrm{Se}_{3}$ ThinFilm Properties. Chemelectrochem. 2019. V. 6. No 11. P. 2937-2944. doi.org/10.1002/celc. 201900457.

2. Gogoli D., Tsurtsumia G. Composition and morphologies of $\mathrm{Mn}-\mathrm{Ni}$ and $\mathrm{Mn}-\mathrm{Ni}-\mathrm{Cu}$ coatings electrodeposited from solution containing complexing ligands EDTA and NTA. Chemical Problems. 2019. V. 17. No 2. P. 205-215.

3. Huseynov G.M., Mammadova N.A., Imanov HA. Obtaining of nanosized compound $\mathrm{Sb}_{2} \mathrm{~S}_{3}$ on the basis of tioacetamide and antimony(III) chloride. Chemical Problems. 2017. V. 15. No 3. P. 329-334. doi.org/10.32737/2221-8688-2017-3-329-334.

4. Majidzade V.A., Cafarova S.F., Aliyev A.Sh., Nuriyev Y.A., Farhatova N.B., Tagiyev D.B. Electrochemical deposition of thin semiconductive Mo-S films. Azerb. Chem. J. 2019. No 1. P. 6-13. doi.org/10.32737/0005-2531-2019-1-6-13.

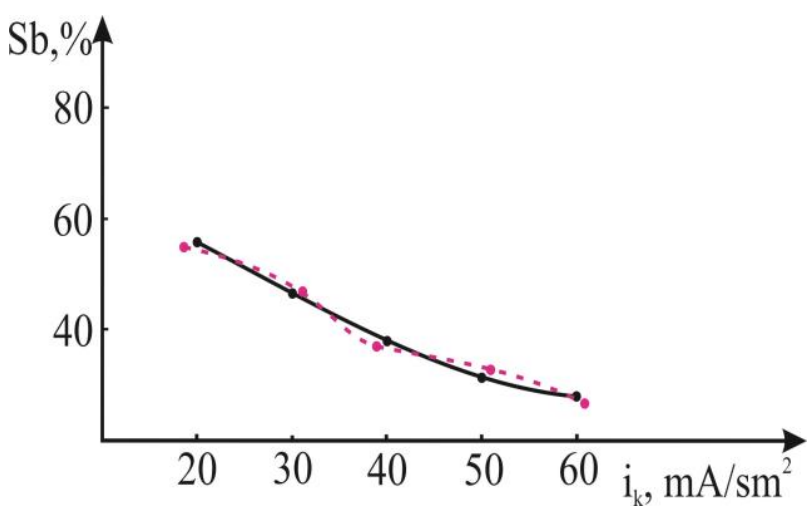

Fig. 3. Dependence of the antimony content in the current density. The composition of the electrolyte (M): $0.05 \mathrm{SbOCl}+0.05 \mathrm{H}_{2} \mathrm{SeO}_{3}+0.007 \mathrm{C}_{4} \mathrm{H}_{6} \mathrm{O}_{6}$; $T=298 \mathrm{~K}$.

5. Eftekhar A. Molybdenum diselenide $\left(\mathrm{MoSe}_{2}\right)$ for energy storage, catalysis, and optoelectronics. Appl. Mater. Today. 2017. V. 8. P. 1-17. doi 10.1016/j.apmt.2017.01.006

6. He W., Zhang H., Zhang Y., Liu M., Zhang X., Yang F. Electrodeposition and Characterization of $\mathrm{CuTe}$ and $\mathrm{Cu}_{2} \mathrm{Te}$ Thin Films. J. Nanomaterials. 2015. Article ID 240525. 5 P. http://dx.doi.org/ $10.1155 / 2015 / 240525$

7. Dergacheva M.B., Nurtazina A.E., Urazov K.A., Gudeleva N.N., Iaskevich V.I., Grigor`eva V.P. E`lektroosazhdenie selenida medi na e`lektrode Mo v rastvore vinnoi` kisloty`. Zhurn. pricl. himii. 2018. T. 91. № 5. C. 664-670.

8. Majidzade V.A. The effect of various factors on the composition of electrolytic thin films $\mathrm{Sb}-\mathrm{Se}$. Chemical Problems. 2018. V. 16. No 3. P. 331336. doi.org/10.32737/2221-8688-2018-3-331-336

9. Aliyev A.Sh., Majidzade V.A., Soltanova N.Sh., Tagiyev D.B., Fateev V.N. Some features of electrochemically deposited CdS nanowires. Chemical Problems. 2018. V. 16. No 2. P. 178-185. doi.org/10.32737/2221-8688-2018-2-178-185

10. Rocca J., García J.L., Ureña M.A., Fontana M., Arcondo B. Temperature Dependence of Electrical Resistance in Ge-Sb-Te Thin Films. Mater. Res. 2019. V. 22. No 2. e20180512.

11. Fateev V.N., Alexeeva O.K., Korobtsev S.V., Seregina E.A., Fateeva T.V., Grigoriev A.S., Aliyev A.Sh. Problems of accumulation and storage of hydrogen. Chemical Problems. 2018. V. 16. No 4. P. 453-483. doi.org/10.32737/2221-8688-20184-453-483

12. Kulova T.L., Nikolaev I.I., Fateev V.N., Aliyev A.Sh. Modern electrochemical systems of energy accumulation. Chemical Problems. 2018. V. 16. No 1. P. 9-34. doi.org/10.32737/2221-8688-2018$1-9-34$ 
13. Majidzade V.A., Guliyev P.H., Aliyev A.Sh., Elrouby M., Tagiyev D.B. Electrochemical Characterization and Electrode kinetics for Antimony Electrodeposition from its Oxychloride Solution in the Presence of Tartaric Acid. J. Mol. Struct. 2017. V. 1136. P. 7-13. doi.org/10.1016/j. molstruc.2017.01.082

14. Majidzade V.A., Aliyev A.Sh., Babanly D.M., Elrouby M., Tagiyev D.B. Investigation of the Electrochemical Reduction Process of the Molybdate Ions in the Tartaric Electrolytes. Acta Chim. Slov. 2019. V. 66. No 1. P.155-162. doi.org/ 10.17344/acsi.2018.4733

15. Majidzade V.A., Guliyev P.H., Aliyev A.Sh., Babayev Y.N., Elrouby M., Tagiyev D.B. Electrochemical behavior of selenite ions in tartaric electrolytes. J. Electrochem. Sci. Eng. 2018. V. 8. No 3. P. 197-204. doi.org/10.5599/jese.490

16. Wang W., Chen G., Wang Z., Wang K., Chen S., Huang Z., Wang X., Chen T., Zhu C., Kong X. Full-inorganic $\mathrm{Sb}_{2}(\mathrm{~S}, \mathrm{Se})_{3}$ solar cells using carbon as both hole selection material and electrode. Electrochim. Acta. 2018. V. 290. P. 457-464. doi.org/ 10.1016/j.electacta.2018.09.087

17. Kamruzzaman M., Liu Ch., Farid Ul Islam A.K.M., Zapien J.A. A Comparative Study on the Electronic and Optical Properties of $\mathrm{Sb}_{2} \mathrm{Se}_{3}$ Thin Film. Semiconductors. 2017. V. 51. No 12. P. 1615-1624. doi.org/10.1134/S1063782617120107
18. Browning R., Kuperman N., Moon B., Solanki R. Atomic Layer Growth of InSe and $\mathrm{Sb}_{2} \mathrm{Se}_{3}$ Layered Semiconductors and Their Heterostructure. Electronics. 2017. V. 6. No 2. P. 27. doi.org/10.3390/ electronics6020027

19. Majidzade V.A., Aliyev A.Sh., Guliyev P.H., Babanly D.M. Electrodeposition of the $\mathrm{Sb}_{2} \mathrm{Se}_{3}$ thin films on various substrates from the tartaric electrolyte. J. Electrochem. Sci. Eng. 2020. V. 10. No 1. P. 1-9 http://dx.doi.org/10.5599/jese.676

20. Majidzade V.A., Aliyev A.Sh., Tagiyev D.B. Electrochemical deposition of $\mathrm{Sb}_{2} \mathrm{Se}_{3}$ thin films semiconductor from tartaric acid solution. Bulgarian Chemical Communications. 2020. V. 52. Special Issue. A. P. 69-74.

21. Samarskii AA. Vvedenie v chislenny`e metody`. M.: Lan`, 2005. $288 \mathrm{~s}$.

22. Samarskii AA, Mihai'lov A. P. Matematicheskoe modelirovanie. Idei. Metody`. Primery`. M.: Fizmatgiz, 1997. $320 \mathrm{~s}$.

23. Bykov V. I., Zhuravlev V. M. Modelirovanie i optimizatciia himiko-tekhnologicheskikh protcessov. Krasnoiarsk: IPTC KGTU, 2002. 298 s.

24. Akhnazarova S.L., Kafarov V.V. Metody optimizatcii e`ksperimenta $\mathrm{v}$ himicheskoi tekhnologii. M.: Vy`sshaia shkola, 1985. $327 \mathrm{~s}$.

25. Kafarov V.V., Metody kibernetiki v himii i himicheskoi tekhnologii. L.: Himiia, 1971. S. 190.

\section{SÜRMӘ-SELEN SISTEMININ ELEKTROKIMYəVI ÇÖKDÜRÜLMO PROSESININ RIYYAZi MODELLOŞDİRILMOSI Və OPTIMALLAŞDIRILMASI}

\section{V.A.Məcidzadə, Q.S.Đliyev, A.Ş.Đliyev, R.H.Hüseynova}

Sürmə-selenid $\left(\mathrm{Sb}_{2} \mathrm{Se}_{3}\right)$ qadağan olunmuş zolağının eni $(1.17 \mathrm{eV})$ və yüksək udulma əmsalına $\left(>10^{5} \mathrm{sm}^{-1}\right)$ görə perspektivli fotoelektrik materialıdır. Son illərdə $\mathrm{Sb}_{2} \mathrm{Se}_{3}$-dən ibarət nazik təbəqəli Günəş elementlərinin enerjini çevirmə effektivliyi getdikcə yüksəlir. Ona görə $\mathrm{d} \partial$, bu materiala olan böyük marağı nəzərə alaraq, təqdim edilən iş elektrokimyəvi üsulla $\mathrm{Sb}-\mathrm{Se}$ nazik təbəqələrinin alınması prosesinin riyazi modelinin və optimallaşdırılmasının öyrənilməsinə həsr edilmişdir. Tədqiqat işi potensiodinamik, potensiostatik və qalvanostatik üsullardan istifadə etməklə müxtəlif şəraitlərdə, $\mathrm{Pt}^{-}, \mathrm{Cu}^{-}$və $\mathrm{Ni}^{-}$elektrodları səthində aparılmışdır. Birgə çökmə prosesinin aparılması ü̧̈ün tartrat elektrolitində sürmə və selenit ionlarının elektroreduksiya proseslərinin kinetika və mexanizmi ayrılıqda tədqiq edilmişdir. Tsiklik polyarizasiya əyriləri, rentgen-faza, SEM-EDX analizləri əsasında müəyyən edilmişdir ki, Sb-Se nazik təbəqələri $\mathrm{Cu}$ elektrodu istisna olmaqla, yalnız Pt və Ni elektrodları üzərinə çökürlər. Riyazi hesablamalar xüsusi olaraq bu proses üçün işlənib hazırlanmış OptimME proqram paketində həyata keçirilmişdir. Müxtəlif faktorların (başlanğıc komponentlərin qatılığı, temperatur, cərəyan sıxlığı və s.) təsiri öyrənilməklə birgə çökmə prosesi üçün optimal elektroliz rejimi və elektrolit tərkibi seçilmişdir ki, bu nəticələrdən də istifadə etməklə, gələcək praktiki məqsədlər üçün prosesin Student və Fişer meyarları təyin edilmiş, reqressiya əmsalları qiymətləndirilmişdir. Alınmış reqressiya tənliyi tərkibində lazım olan miqdarda $\mathrm{Sb}$ olan $\mathrm{Sb}-\mathrm{Se}$ ərintisini almağa imkan verən elektrolitin tərkibini və elektroliz şəraitini müəyyən edir. Aparılan hesablamalar və təcrübi nəticələr göstərir ki, Sb-Se ərintisi üçün alınmış reqressiya tənliyinin xətası $\varepsilon=6.4 \%$ təşkil edir.

Açar sözlor: Sb-Se təbəqalari, reqressiya tanliyi, Student va Fişer meyarları, riyazi modellaşmə. 


\section{МАТЕМАТИЧЕСКОЕ МОДЕЛИРОВАНИЕ И ОПТИМИЗАЦИЯ ПРОЦЕССА ЭЛЕКТРООСАЖДЕНИЯ СИСТЕМЫ СУРЬМА-СЕЛЕН}

\section{В.А.Меджидзаде, Г.С.Алиев, А.Ш.Алиев, Р.Г.Гусейнова}

Селенид сурьмы $\left(\mathrm{Sb}_{2} \mathrm{Se}_{3}\right)$ является отличным фотоэлектрическим поглотителем благодаря своему высокому

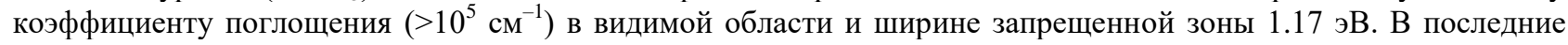
годы эффективность преобразования энергии тонкопленочных солнечных элементов $\mathrm{Sb}_{2} \mathrm{Se}_{3}$ постепенно повышается. Поэтому, учитывая большой интерес к этому материалу, данная работа посвящена изучению математической модели для оптимизации процесса получения тонких пленок $\mathrm{Sb}-\mathrm{Se}$ электрохимическим методом. Исследование проводилось потенциодинамическим, потенциостатическим и гальваностатическим методами, в различных условиях на $\mathrm{Pt}^{-}, \mathrm{Cu}^{-}$и $\mathrm{Ni}^{-}$электродах. Для совместного электрохимического осаждения кинетика и механизм электровосстановления ионов сурьмы и селенита в винной кислоте исследовались отдельно. На основании циклических поляризационных кривых, рентгенофазового и SEM-EDX анализов обнаружено, что тонкие пленки Sb-Se осаждаются на электроды Pt и Ni, кроме электрода Cu. Математические расчеты были выполнены в программном пакете OptimME с использованием специально разработанного для этого процесса программного обеспечения. С изучением влияния различных факторов (концентрация исходных компонентов, температуры, плотности тока и т.д.) были выбраны оптимальный режим электролиза и состав электролита для процесса совместного осаждения. По этим результатам для будущих целей были назначены критерии Стьюдента и Фишера и оценены коэффициенты регрессии. Полученное уравнение регрессии определяет содержание электролита и условия электролиза, которое позволяет осаждать сплав $\mathrm{Sb}-\mathrm{Se}$ содержащий в составе необходимое количество $\mathrm{Sb}$. Расчеты и экспериментальные результаты показывают, что погрешность уравнения регрессии для получения сплава $\mathrm{Sb}-\mathrm{Se}$ составляет $\varepsilon=6.4 \%$.

Ключевье слова: пленки Sb-Se, уравнение регрессии, критерии Стьюдента и Фишера, математическое моделирование. 